\title{
Bíblia e Liturgia: da Dei Verbum à Verbum Domini
}

\author{
Bible and Liturgy: \\ starting from Dei Verbum to Verbum Domini
}

Luiz Fernando Ribeiro Santana

\section{Resumo}

Abordar o binômio "bíblia e liturgia" é continuar a respirar o vento do novo pentecostes inaugurado pelo Concílio Vaticano II. De lá até os nossos dias a Igreja não cessa de se debruçar sobre o tema da Sagrada Escritura que se torna Palavra de vida e salvação sempre que proclamada em nossas assembléias litúrgicas. Com toda a propriedade teológica a Exortação Apostólica Verbum Domini afirma que a liturgia é "âmbito privilegiado onde Deus nos fala no momento presente de nossa vida (n. 52). Essa afirmação outra coisa não é senão uma releitura atualizante da teologia do Concílio Vaticano II.

Palavras-chave: Bíblia. Liturgia. Dei Verbum. Verbum Domini. Lectio divina.

\begin{abstract}
Approach the binomial "bible and liturgy" is to continue to breathe the wind of the new Pentecost inaugurated by the Second Vatican Council. From there until today the Church does not cease to lean over on the theme of Sacred Scripture which becomes the word of life and salvation whenever proclaimed in our liturgical assemblies. With all the theological property, the Apostolic Exhortation Verbum Domini affirms that the liturgy is "a privileged ambit where God speaks to us in the present moment of our life" (n. 52). This
\end{abstract}


statement is nothing more than an up-to-date rereading of the theology of the Second Vatican Council.

Keywords: Bible. Liturgy. Dei Verbum. Verbum Domini. Divine lectio.

\section{Introdução}

É com imensa alegria que oferecemos este nosso artigo à nossa revista "Atualidade Teológica" e o dedicamos a todos os que dele puderem tirar alguma forma de proveito para suas reflexões. Ele quer ser um contributo para a segunda revista temática do ano de 2017, que se debruçará sobre a abordagem "Culto e Vida Cristã".

Ainda respirando o perfume do jubileu de ouro do encerramento do Concílio Vaticano II -um marco epocal para a Igreja e o mundo de nossos dias - achamos por bem eleger aquele tema que também foi escolhido pelo Concílio como fonte de sua inspiração e coração pulsante de tudo aquilo que nele foi tratado ao longo de três anos: a Palavra de Deus. Sabemos, outrossim, que não se pode atingir o cerne da proposta conciliar no tocante à revelação que Deus faz de si mesmo sem considerá-la em total sintonia com o mistério da liturgia. Ora, o Vaticano II e o magistério pós- conciliar insistem naquilo que será afirmado pelo Ordo Lectionum Missae, n. 1: “O Concílio Vaticano II, o magistério dos sumos pontífices e os vários documentos promulgados depois do mesmo Concílio por diversas Congregações da Santa Sé apontam muitos aspectos sobre o valor da Palavra de Deus e sobre a restauração do uso da Sagrada Escritura em toda a celebração litúrgica".

Com o intuito de realçar teologicamente a densidade dessa declaração dividimos o itinerário que estamos por percorrer em três fases: partindo da Constituição conciliar que já foi qualificada como a "pérola" da teologia do Vaticano II e a "carta magna" da revelação contida na Palavra de Deus - a Dei Verbum -, desaguamos na Exortação Apostólica pós-sinodal Verbum Domini de Bento XVI, um fruto amadurecido e que se tornou suculento por trazer em seu bojo vários desdobramentos que, em germe, foram profeticamente anunciados pela Constituição sobre a divina revelação. Na verdade, a textura final da Verbum Domini é potenciada pelo sopro de vida que, ao longo de cinco décadas, assistiu e animou a Igreja em seu incansável interesse pela redescoberta da Palavra de Deus. A terceira fase de nossa proposta nos convida 
a focalizar um tema que foi tratado com grande apreço e carinho pela $D e i$ Verbum e pela Verbum Domini: a lectio divina. Trata-se de uma realidade que tem despertado grande interesse nas diversas esferas da vida eclesial e tem se revelado em seu alcance ecumênico e bastante promissor nos âmbitos da espiritualidade e da pastoral da Igreja.

Ao apresentarmos esse contributo estamos cientes da modéstia de nossa proposta e conscientes de que nela apenas se insinua uma pequena parcela daquilo que a temática "Bíblia e Liturgia" encerra. Ao mesmo tempo, aqui fazemos uma "profissão de fé" no grão de mostarda: é a "menor de todas as sementes", mas, uma vez semeado, "deita grandes ramos" (cf. Mc 4,31-32).

\section{Dei Verbum: a "carta magna" da Palavra de Deus}

Com toda a probabilidade, a Dei Verbum foi a constituição conciliar mais discutida e elaborada, conforme poderiam demonstrar as etapas de suas várias redações até a sua confecção final. ${ }^{1}$ Promulgada no dia 18 de novembro de 1965 , essa constituição dogmática se apresenta como um texto breve e de profunda densidade. Segundo R. Latourelle, ela poderia ser considerada a "pérola" do Concílio e a "carta magna" da Palavra de Deus. ${ }^{2}$ Em outro lugar ele ainda afirma que ela poderia até mesmo ser tida como o "documento fonte" do Vaticano II e que toda a sua mensagem possa ser reassumida nessa constituição. ${ }^{3}$ Outras imagens e expressões bastante enfáticas foram aplicadas à Dei Verbum por teólogos que, direta ou indiretamente, tiveram alguma forma de participação no seu conteúdo de densidade e espessura teológica. ${ }^{4}$

O Concílio Vaticano II é "atravessado pela Dei Verbum, que representa,

\footnotetext{
${ }^{1}$ CAPIZZI, N. Dei Verbum. Storia, commento recezione. Roma: Studium, 2015, pp. 11-46; PACOMIO, L. Dei Verbum. Genesi della costituzione sulla divina rivelazione. Torino: Marietti, 1971.

${ }^{2}$ LATOURELlE, R. Come Dio si rivela ao mondo. Assisi: Cittadella, 2000, p. 5.

${ }^{3}$ LATOURELLE, R. (Org.). Vaticano Il. Bilancio e prospettive. Venticinque anni dopo. Assisi: Cittadella, 1987, p. 17.

${ }^{4}$ H. De Lubac, por exemplo, diz que a Dei Verbum é "o portal de ingresso e o fundamento do edifício teológico do Vaticano II". E. Bianchi crê que o texto dessa constituição dogmática seja, em si mesmo, uma obra orgânica. Ele deve ser considerado como um ponto de partida para a compreensão eclesial da Palavra de Deus e da sua centralidade na vida dos crentes. Segundo E. Bianchi, trata-se de um texto central do Vaticano II - cf. BIANCHI, E. "La centralità della Parola di Dio". In: ALBERIGO, G.; JOSSUA, J. (Orgs.). Il Vaticano II e la Chiesa. Brescia: Paideia, 1985, p. 162.
} 
de certo modo, a sua alma". ${ }^{5}$ Certamente essa importância da constituição dogmática sobre a divina revelação deve ser também atribuída a dois fatores. Em primeiro lugar ela foi elaborada ao longo do processo de maturação do Concílio Vaticano II. Não poderíamos imaginá-la, por exemplo, sem considerar a maturidade teológica que se encontra nas três outras constituições do Concílio - Sacrosanctum Concilium, Lumen Gentium e Gaudium et Spes, com as quais mantém íntima e profunda relação - e com o restante das demais produções conciliares.

Em segundo lugar, como pensar na Dei Verbum sem as suas raízes remotas e imediatas? Referimo-nos ao transfundo de alguns documentos magisteriais que a precederam e nela imprimiram um importante timbre: Providentissimus Deus (1893), Spiritus Paraclitus (1929) e Divino afflante Spiritu (1943). ${ }^{6}$ Esses documentos assinalam fortemente a importância e a centralidade do papel que a Sagrada Escritura teve na vida da Igreja católica ao longo do século XX. Não se pode ignorar, entretanto que esse verdadeiro despertar epocal no que concerne à redescoberta da capital importância da Bíblia na vida da Igreja e dos fiéis batizados deveu-se, particularmente, ao "Movimento Litúrgico"?

A linguagem de composição da Dei Verbum em seus seis capítulos é essencialmente bíblico-patrística. ${ }^{8}$ Além do mais, "pela primeira vez na história da Igreja um Concílio enfrentou o tema da revelação sem a necessidade de responder e corrigir determinados problemas". ${ }^{9}$ Em grande parte isso se

\footnotetext{
${ }^{5}$ TESTAFERRI, F. La Parola viva. Assisi: Cittadella, 2009, p. 14.

${ }^{6}$ MARTINEZ DE OLIVEIRA, F. “A constituição dogmática Dei Verbum e o Concílio Vaticano II”. Cadernos de Teologia Pública 102 (2015), pp. 5-8.

${ }^{7}$ Cf. MARSILI, S. "A liturgia. Momento histórico da salvação”. In: NEUNHEUSER, B. et alii. A Liturgia. Momento histórico da salvação. Volume I. São Paulo: Paulinas, 1987, pp. 39-190; BOTTE, B. O Movimento Litúrgico. São Paulo: Paulinas, 1978.

${ }^{8}$ Texto de cunho ecumênico - portanto, não movido por qualquer tipo de razão apologética -, a Dei Verbum procura suscitar na vida da Igreja e de cada crente uma tomada de consciência cada vez mais viva acerca da necessidade permanente de uma relação pessoal e eclesial para com a Palavra de Deus. Texto simples, denso, breve, bem ordenado e preso ao essencial, o nosso documento se preocupa com o concreto da vida da Igreja e dos cristãos. Em seus seis capítulos, a Dei Verbum tem o mérito de reconstruir todo o projeto salvífico de Deus sob o signo da unidade: entre o Revelador e a revelação, das Escrituras, entre os dois testamentos, de toda a economia divina. São estes os capítulos que formam a Dei Verbum: I) A revelação; II) A transmissão da revelação; III) A inspiração divina e a interpretação da Sagrada Escritura; IV) O Antigo Testamento; V) O Novo Testamento; VI) A Sagrada Escritura na vida da Igreja (CONCÍLIO VATICANO II. Constituição Dogmática Dei Verbum sobre a revelação divina. São Paulo: Paulinas, 1966. Doravante este documento será citado como DV).
}

${ }^{9}$ TESTAFERRI, F., op. cit., p. 18. 
deve ao fato de o Vaticano II ter sido um concílio de natureza eminentemente pastoral, aberto ao diálogo com as diversas confissões cristãs e o mundo e, por conseguinte, livre de qualquer intenção anatematizante - esse foi o firme propósito e desejo de João XXIII ao convocá-lo. "E isso já é um ato de fé na Palavra de Deus. Manifesta a convicção de que a verdade é luminosa por si mesma e carrega em si a própria força de convencimento. Não há necessidade de se recorrer a outra coisa para torná-la credível". ${ }^{10}$

A centralidade do primado da Palavra de Deus é o fio de ouro que norteia e perpassa toda a constituição dogmática sobre a divina revelação. Diante desse panorama optamos por privilegiar o proêmio do documento como paradigma de nossa abordagem - a liturgia como locus privilegiado para a celebração da Palavra de Deus. A razão dessa opção consiste no fato de ser esse incipit como que a síntese da mensagem contida na Dei Verbum.

A constituição é batizada com um nome (Dei verbum) extraído da frase inicial de sua versão latina (Dei verbum religiose audiens et fidenter proclamans [...]), a qual contém em si mesma a proposta a ser desdobrada em seus seis capítulos: "Este sagrado Concilio, ouvindo religiosamente a Palavra de Deus e proclamando-a com confiança [...]". Nessa abertura do proêmio já se pode perceber toda a dinâmica do projeto de Deus no que se refere ao dom da revelação que faz de si mesmo: comunicar-se aos homens para que, livremente, eles lhe correspondam - e este é, fundamentalmente, o princípio dinâmico que vivifica o mistério da liturgia e lhe confere sentido.

$\mathrm{O}$ incipit do documento nos coloca diante de uma assembleia atenta e disposta à escuta - referimo-nos à própria sinodalidade dos padres conciliares e demais membros que a compõem, que se encontram em torno da Bíblia e têm como centro de gravidade a Palavra de Deus. Essa congregação, composta de clérigos e leigos, reunida com o bispo de Roma, tipifica e representa todo o povo de Deus. Por conseguinte, é de extrema importância o testemunho que lega à Igreja de todos os tempos: a primazia absoluta da escuta da Palavra como condição sine qua non para anunciá-la "com desassombro".

A assembleia conciliar, reunida na unidade do Espírito Santo, se dispõe a acolher a revelação divina a fim de se tornar serva dessa mesma Palavra acolhida na fé. Com essa imagem o Concílio Vaticano II realiza uma verdadeira revolução copernicana no que concerne à Igreja. Diferentemente da concepção

${ }^{10}$ MAGGIONI, B. "Impara a conoscere il volto di Dio nelle parole di Dio". Commento alla Dei Verbum. Padova: Messaggero Padova, 2009, p. 14. 
pré-conciliar - quando prevalecia a mentalidade de uma ecclesia docens, representada pela imagem de uma pirâmide, segundo a qual a Igreja deveria ensinar e o povo obedecer ${ }^{11}$ - aqui nos encontramos diante da "subversão da pirâmide". Segundo a concepção da nossa constituição dogmática, a ecclesia audiens é condição indispensável para que efetivamente se plasme a ecclesia docens. Dessa forma, o reconhecimento indiscutível do primado da Palavra de Deus, à qual toda a Igreja é chamada a estar a serviço, apresenta-se-nos como uma novidade qualitativa da Dei Verbum.

A Igreja é mistério que visibiliza, através da escuta da Palavra e da graça sacramental, a vida do Pai, do Filho e do Espírito Santo, a grande comunhão que funda a nossa comunhão, nas três grandes fases da história salvífica do povo de Deus na sua história do primeiro testamento, através das várias economias dos patriarcas e dos profetas. É nessa história que se insere Jesus, o Novo Testamento e, enfim, nós, a Igreja. É essa a grande história da salvação na qual todos nos encontramos. ${ }^{12}$

O incipit da Dei Verbum toma como fundamento a autoridade escriturística contida em 1Jo 1,2-3: “[...] Nós vos anunciamos a vida eterna que estava voltada para o Pai e nos apareceu - o que vimos e ouvimos vo-lo anunciamos para que estejais também em comunhão conosco. E a nossa comunhão é com o Pai e com o seu Filho Jesus Cristo". Estamos diante de um texto dinâmico e cheio de vivacidade. Ele se mostra como um potente reflexo da experiência da comunidade joaneia e, por extensão, da vida de fé da Igreja primitiva. Sua carga querigmática poderia nos remeter ao contexto litúrgico da perícope: nos ambientar a uma comunidade reunida que acolhe com fé a Escritura proclamada. O "nós" do anúncio da mensagem do apóstolo transparece uma Igreja em permanente estado assembleal e que constrói sua identidade no próprio ato de se congregar. Esse "nós" vem eivado de uma carga de experiência cúlticocelebrativa, de testemunho e de anúncio solene de uma "epifania": "Nós vos anunciamos a vida eterna que estava voltada para o Pai e nos apareceu". A meta de tal proclamação litúrgica é a comunhão - com Deus, com o corpo eclesial e com todos os homens: "[...] para que estejais também em comunhão conosco. E a nossa comunhão é com o Pai e com o seu Filho Jesus Cristo".

\footnotetext{
${ }^{11}$ CALATI, B. "Rivelazione e/o Tradizione. Il capitolo II della Dei Verbum". In: CALATI, B. et alii. Un documento dimenticato. La "Dei Verbum". Reggio Emilia: San Lorenzo, p. 12. ${ }^{12}$ Ibidem.
} 
È importante assinalar que, além da autoridade da Escritura, o incipit da Dei Verbum valoriza também o magistério eclesial (representado pelos concílios de Trento e Vaticano I) e pela Tradição, muito bem ilustrada por uma citação do De Catechizandis rudibus, de Santo Agostinho. O que será ulteriormente desenvolvido no documento já encontra aqui a sua síntese, a saber: a interpretação e a transmissão da revelação divinamente inspirada, contida na Sagrada Escritura, realiza-se na vida da Igreja, sobretudo no contexto do culto divino. ${ }^{13}$

"Dei verbum religiose audiens et fidenter proclamans" ("Ouvindo religiosamente a Palavra de Deus e proclamando-a com confiança") é, portanto, a solene abertura que descerra o cenário da constituição sobre a revelação divina. Essa formulação de abertura foi um epitáfio conscientemente escolhido pelos padres conciliares. Ela torna-se, doravante um leitmotiv não só para o documento em si mesmo, como também para o mistério da Igreja, em seu ser e em sua missão. Isso quer dizer que não se pode, à luz da inspiração do Vaticano II, pensar em uma autêntica e eficaz proclamação da Palavra de Deus sem que se dê absoluta primazia à sua permanente "escuta religiosa".

O verbo "escutar" (akoúein), típico da teologia e espiritualidade joaneia, somente pode ser devidamente compreendido na lógica do mistério da encarnação. Uma vez que a Palavra se encarnou (cf. Jo 1,1-14), ela se tornou audível, visível, próxima, palpável. Doravante, ela pode se tornar a fonte da experiência e do testemunho do Ressuscitado. ${ }^{14} \mathrm{O}$ testemunho da absoluta primazia da escuta da Palavra, ecoado pela ecclesia audiens, orans e docens da comunidade de João é, em última análise, o eco da transmissão vivida e testemunhada pelo povo de Deus da primeira aliança, fundamento e coração da espiritualidade de Israel: "Ouve, ó Israel: Iahweh nosso Deus é o único Senhor [...] (Dt 6,4) - retomado intencionalmente por Jesus (cf. Mc 12,29). Trata-se da escuta da Palavra que está contida nas Sagradas Escrituras. ${ }^{15}$

"Os apóstolos, transmitindo o que eles mesmos receberam [...]. Ora, estas tradições, recebidas dos apóstolos abrangem tudo quanto contribui para a santidade do povo de Deus e para o aumento da fé; assim, a Igreja, na sua

\footnotetext{
${ }^{13}$ Cf. DV, n.1: "Por isso, segundo os Concílios Tridentino e Vaticano I, [O sagrado Concílio] entende propor a genuína doutrina sobre a Revelação divina e a sua transmissão, para que o mundo inteiro, ouvindo, acredite na mensagem da salvação, acreditando espere, e esperando ame".

${ }^{14}$ BIANCHI, E. L'amore vince la morte. Commento esegetico spirituale alle lettere di Giovanni. Torino: San Paolo, 2008, pp. 23-34.

${ }^{15}$ Cf. DV, n. 24.
} 
doutrina, vida e culto, perpetua e transmite a todas as gerações tudo aquilo que ela própria é e tudo quanto acredita". ${ }^{16}$ Em outros passos, como é o caso dos números 21 e 23 da Dei Verbum, se verifica a preocupação do Concílio em vincular a Sagrada Escritura ao culto. Contudo é no número 25 que isso se verifica de forma eloquente. Nele, o documento explicita a necessidade de se manter "contato íntimo com as Escrituras" - sobretudos os que presidem as assembléias litúrgicas e aqueles que trabalham com o anúncio da Bíblia. E o parágrafo, por fim, explicita que é, "sobretudo", nas celebrações litúrgicas que as "grandíssimas riquezas da palavra divina" são transmitidas. Mais adiante afirma o parágrafo que a "sagrada liturgia" é o momento privilegiado para se "tomar contato" com o texto sagrado. O nexo intrínseco e vital existente entre a teologia da Dei Verbum e a liturgia é, portanto, um dado de fato. Cabe-nos, em seguida, verificar a explicitação e aprofundamento desse "dado de fato" na Exortação Apostólica pós-sinodal Verbum Domini - ocasião privilegiada de confronto de dois documentos de envergadura ímpar no que concerne à nossa proposta temática.

\section{A Palavra de Deus na vida da Igreja à luz da Verbum Domini}

A Exortação Apostólica pós-sinodal Verbum Domini - fruto da XII Assembleia geral ordinária do Sínodo dos Bispos, realizada de 5 a 26 de outubro de 2008, no Vaticano - tem como escopo tratar da Palavra de Deus na vida e na missão da Igreja.

Ao valorizar e investigar o evento sempre novo e atual da Palavra de Deus, a Exortação Apostólica pós-sinodal se apresenta como um marcante ponto de chegada da teologia proposta pelo Concílio Vaticano II e, simultaneamente, como ponto de partida de uma consciência eclesial em processo de maturação no que se refere ao coração da vida e da missão da Igreja: o anúncio e a celebração da Palavra de Deus. "Das constituições Sacrosanctum Concilium e Dei Verbum do Vaticano II até a Exortação Apostólica pós-sinodal Verbum Domini de Bento XVI existe um progressivo desenvolvimento de uma doutrina e de uma proposta pastoral que na Verbum Domini encontra sua confirmação autorizada e um verdadeiro progresso de enriquecimento". ${ }^{17}$

Ao tratar da natureza da Palavra de Deus no que se refere à vida e à missão

\footnotetext{
${ }^{16} \mathrm{DV}, \mathrm{n} .8$.

${ }^{17}$ AUGÉ, M. "La Parola di Dio celebrata. Dalla Sacrosanctum Concilium alla Dei Verbum". Rivista Liturgica 2 (2012), p. 307.
} 
da Igreja, essa Exortação assume como paradigma o prólogo do Evangelho de João, focalizando particularmente o versículo 14: "E o Verbo se fez carne e habitou entre nós". A motivação de tal escolha é o fato dessa passagem ser "um texto admirável que dá uma síntese de toda a fé cristã". ${ }^{18}$

À luz da pedagogia divina - lida e interpretada na ótica da experiência da "encarnação da Palavra" ao longo da economia salvífica - a irrupção do Verbo na história dos homens apresenta-se como um evento salvífico e criador. Para exemplificar isso bastaria tomar o modelo encontrado em Ex 3,7-8-perícope fortemente carregada de um páthos divino desejoso de salvar e recriar o povo eleito: "Eu vi, eu vi a miséria do meu povo (...). Ouvi o seu clamor (...); pois conheço as suas angústias. Por isso desci (...), para fazê-los subir (...)". Tal potência salvífico-criativa do Lógos eterno, que opta por se fazer história na história dos homens, encontra a sua máxima expressão no mistério da encarnação do Verbo, dado bastante enfático na Exortação Apostólica de Bento XVI: “(...) Vemo-nos colocados diante do mistério de Deus que se comunica a si mesmo por meio do dom da sua Palavra". ${ }^{19}$

O documento pós-sinodal reassume, dessa forma, o critério inscrito na própria tessitura bíblica, a saber, a interpretação da Palavra de Deus à luz da fé eclesial. Com esse tema o Documento quis "debruçar-se" sobre o bloco dedicado à hermenêutica da Sagrada Escritura na Igreja (n. 29-49): "E precisamente a ligação intrínseca entre Palavra e fé põe em evidência que a autêntica hermenêutica bíblica só pode ser feita na fé eclesial". ${ }^{20}$ É importante mostrar que, valendo-se de um método bastante utilizado pelos Padres da Igreja, a Exortação Apostólica opta por uma leitura de unidade das Escrituras. Nesta, o "Novo Testamento reconhece o Antigo Testamento como Palavra de Deus e, por conseguinte, admite a autoridade das Sagradas Escrituras do povo judeu". ${ }^{21}$

Além do mais - e este é o escopo deste artigo - o documento sublinha que o método tipológico inerente à Sagrada Escritura e característico da patrística encontra o seu contexto vital na celebração litúrgica da Igreja, razão pela qual não se pode descurar o título que encabeça os números de 52 a 71 da

\footnotetext{
${ }^{18}$ BENTO XVI. Exortação apostólica pós-sinodal Verbum Domini. São Paulo: Paulinas, 2010, n. 5 (Doravante citado como VD).

${ }^{19} \mathrm{VD}, \mathrm{n} .1$.

${ }^{20} \mathrm{VD}$, n. 29.

${ }^{21} \mathrm{VD}, \mathrm{n}$. 40. A essa altura o texto menciona o Documento da PONTIFÍCIA COMISSÃO BÍBLICA. O povo judeu e suas Sagradas Escrituras. São Paulo: Paulinas, 2002, n. 3-5.
} 
Exortação: "Liturgia, lugar privilegiado da Palavra de Deus". Nessas últimas décadas do pós-Concílio, aliás, esse tema tem vindo à baila, tanto na esfera da teologia litúrgica como na da teologia bíblica. Um exemplo disso é o estudo de M. Magrassi acerca da tipologia bíblico-patrístico-litúrgica da Palavra de Deus, onde Palavra e Rito se valem de uma unidade orgânica no âmbito da celebração. ${ }^{22}$

É do nosso interesse gravitar criticamente em torno do número 52 da Exortação Apostólica pós-sinodal..$^{23}$ Nele encontramos a seguinte afirmação: a celebração litúrgica é "o âmbito privilegiado onde Deus nos fala no momento presente da nossa vida: fala hoje ao seu povo, que escuta e responde". Nesse sentido se pode dizer que a assembleia litúrgica é o terreno fecundo e privilegiado para se acolher e responder à automanifestação de Deus por meio de sua Palavra. Com efeito, "a palavra escrita existe como documento; a palavra proclamada na assembleia existe como palavra relacional, Palavra viva, pois, no momento em que sai da boca de Deus, graças ao ministério do leitor, ela chega aos ouvidos e ao coração do povo reunido. OLM 4 afirma que nessa palavra 'Cristo está presente, o qual, realizando o seu mistério de salvação, santifica os homens e presta ao Pai um culto perfeito'". ${ }^{24}$

\footnotetext{
22 MAGRASSI, M. Viver a Palavra. São Paulo: Paulinas, 1984, pp. 9-41.

${ }^{23}$ Cf. De ZAN, R. “Verbum Domini” y Liturgia. Phase 302 (2011), pp. 147-160.

${ }^{24}$ ALDAZÁBAL, J. (Org.). Mesa da Palavra. Volume. I. Elenco das leituras da Missa. São Paulo, Paulinas, 2007, n. 4._(Doravante citado como OLM). Trata-se de um documento elaborado pela Sagrada Congregação para os Sacramentos e o Culto Divino, impresso em sua primeira edição no ano de 1969. Em 1985, este documento foi publicado no Brasil como A Palavra de Deus na Missa, pelas Edições Paulinas. No ano de 2007, este mesmo documento foi reeditado - após a sua segunda edição oficial - pela mesma editora com o seguinte título: $A$ Mesa da Palavra. vol. I. Elenco das leituras da Missa. AUGÉ, M. op. cit., p. 310. O termo dabar, usado na bíblia hebraica, está longe de ser uma pura representação abstrata dirigida ao conhecimento, e jamais pode ser reduzida à comunicação fria e objetiva do "pensamento" de Deus em relação aos homens. Ao contrário, dabar apresenta-se no texto sagrado com uma realidade profundamente dinâmica que age, cria, intervém na história, torna possível a existência humana a fim de orientar-lhe o caminho. Esse termo, dessa forma, poderia ser traduzido simultaneamente como "palavra" e "acontecimento": uma "palavra-ação". "Como a chuva e a neve descem do céu e para lá não voltam, sem terem regado a terra, tornando-a fecunda e fazendo-a germinar (...), tal ocorre com a palavra que sai da minha boca: ela não volta mim sem efeito; sem ter cumprido o que eu quis e realizado o objetivo de sua missão" (Is 55,10-11). Essa declaração contida no dêutero-Isaías expressa de maneira incisiva o que a revelação veterotestamentária concebia a respeito da Palavra de Deus. Além do mais, aí encontramos dois aspectos a serem levados em conta: o caráter de dom da Palavra e os seus efeitos imediatos sempre que for proclamada. A imagem da chuva e da neve mostra claramente que a terra - o coração do homem - não pode ser fecunda sem o dom que vem do céu. De igual maneira, segundo a mensagem profé-
} 
Em virtude do que estamos considerando, passemos a considerar o valor e a importância da proclamação litúrgica da Palavra de Deus.

Em dois momentos a Verbum Domini - retomando a teologia da constituição litúrgica Sacrosanctum Concilium - explicita o papel fundamental da Palavra de Deus durante o momento celebrativo: "É enorme a importância da Sagrada Escritura na celebração da Liturgia (...)" e "[o próprio Cristo] está presente na sua palavra, pois é Ele que fala ao ser lida na Igreja a Sagrada Escritura". ${ }^{25}$ Embora o nosso interesse seja mostrar a presença de Cristo na Palavra proclamada, convém mostrar a amplitude da visão conciliar no tocante a essa mesma presença em suas variadas modalidades. Exemplo típico disso é a clássica afirmação do documento conciliar:

De fato, para levar a efeito obra tão importante, Cristo está sempre presente em sua Igreja, sobretudo nas ações litúrgicas. Presente está no sacrifício da missa, tanto na pessoa do ministro, pois aquele que agora oferece pelo ministério dos sacerdotes é o mesmo que, outrora, se ofereceu na cruz, quanto sobretudo sob as espécies eucarísticas. Presente está pela sua força nos sacramentos, de tal forma que, quando alguém batiza, é Cristo mesmo que batiza. Presente está pela sua Palavra, pois é Ele mesmo que fala quando se leem as Sagradas Escrituras na Igreja. Está presente finalmente quando a Igreja ora e salmodia, Ele que prometeu: "Onde dois ou três estiverem reunidos em meu nome, aí estarei no meio deles" (Mt 18,20). ${ }^{26}$

O Concílio Vaticano II, maturado ao longo das décadas do Movimento Litúrgico - essencialmente forjado pela teologia bíblica e pela paixão das Escrituras no culto divino -, não só realça a importância vital da Palavra de Deus na vida da Igreja como ainda destaca a presença de Cristo através da Palavra proclamada na liturgia. "Nas diferentes celebrações e nas diversas assembleias das quais os fiéis participam de maneira admirável, exprimemse os múltiplos tesouros da única Palavra de Deus (...)". ${ }^{27}$ Essa única Palavra se converte em acontecimento sempre novo, em "hoje" da salvação: Jesus Cristo. Isso nos é ilustrado pela declaração que Jesus fez numa celebração da

tica, a Palavra é uma mensageira que cumpre, infalivelmente, o encargo que lhe foi confiado: encontra-se a serviço do desígnio divino, levando-o ao seu pleno cumprimento.

${ }^{25}$ VD, n. 52. Cf. BECKÄUSER, A. (Org.). Sacrosancum Concilium. Texto e comentário. São Paulo: Paulinas, 2012, n. 24 e 7 (Doravante citado como SC).

${ }^{26} \mathrm{SC}, \mathrm{n} .7$.

${ }^{27}$ OLM, n. 3. 
Palavra, na Sinagoga de Nazaré. Imediatamente após a proclamação de uma passagem do trito-Isaías, ele afirma: "Hoje se cumpriu aos vossos ouvidos essa passagem da Escritura" (Lc 4,21).

A realidade da presença de Cristo na liturgia pode ser ilustrada enfaticamente no contexto da celebração da Eucaristia, onde se torna marcante o que poderíamos denominar de "teologia da presença de Cristo" na Liturgia da Palavra. Ao tratar da Palavra de Deus no âmbito da Eucaristia, Bento XVI, na esteira de vários pronunciamentos do Magistério, reafirma que esta foi também uma proposta intencional do Concílio Vaticano II. ${ }^{28}$

A Sagrada Escritura, proclamada na Liturgia da Palavra, evoca e torna atual toda a economia da salvação que, em Cristo, tem o seu pleno cumprimento. Sugestivo a esse respeito é o episódio dos "Discípulos de Emaús". Na tarde da Páscoa, o Ressuscitado se coloca entre dois de seus discípulos que se encontravam desolados e incapazes de reconhecer o Senhor. Em determinada altura do percurso, Lucas diz que Jesus retoma a revelação veterotestamentária e dela se faz um hermeneuta qualificado: "E, começando por Moisés e por todos os profetas, interpretou-lhes em todas as Escrituras o que a ele dizia respeito" (Lc 24,27). Dado importante a se notar, é o fato de a economia da primeira Aliança, toda ela, encontrar no Cristo pascal o seu cumprimento, o que fica também bastante marcado no seguimento da perícope: "Era preciso que se cumprisse tudo o que está escrito sobre mim na Lei de Moisés, nos Profetas e nos Salmos" (v. 44). ${ }^{29}$

A proclamação da Palavra na liturgia nos torna "contemporâneos" do Mistério de Cristo e nos coloca em comunhão com a sua presença. Celebrando o memorial da promessa feita a Abraão e levada a cabo na "plenitude dos

${ }^{28} \mathrm{VD}, \mathrm{n}$. 54. A esse respeito é importante conferir aquilo que Bento XVI afirma no n. 55 da Verbum Domini: "Palavra e Eucaristia correspondem-se tão intimamente que não podem ser compreendidas uma sem a outra: a Palavra de Deus faz-Se carne, sacramentalmente, no evento eucarístico. A Eucaristia abre-nos à inteligência da Sagrada Escritura, como esta, por sua vez, ilumina e explica o Mistério eucarístico. Com efeito, sem o reconhecimento da presença real do Senhor na Eucaristia, permanece incompleta a compreensão da Escritura. Por isso, "à palavra de Deus e ao mistério eucarístico a Igreja tributou e quis e estabeleceu que, sempre e em todo o lugar, se tributasse a mesma veneração, embora não o mesmo culto".

${ }^{29}$ Idem, n. 52: "Por isso, para a compreensão da Palavra de Deus, é necessário entender e viver o valor essencial da ação litúrgica. Em certo sentido, a hermenêutica da fé relativamente à Sagrada Escritura deve ter sempre como ponto de referência a liturgia, onde a Palavra de Deus é celebrada como palavra atual e viva: 'A Igreja, na liturgia, segue fielmente o modo de ler e interpretar as Sagradas Escrituras seguido pelo próprio Cristo, quando, a partir do hoje do seu evento, exorta a perscrutar todas as Escrituras"”. 
tempos" (Gl 4,4), a Palavra anunciada na liturgia torna-se epifania da presença definitiva do Emanuel, o "Deus-conosco" (cf. Mt 1,23; Is 7,14). Ele mesmo é o euangélion perenemente proclamado e tornado atual, evento de salvação para todos os que o acolhem na fé.

A nova etapa da economia salvífica iniciada com o "tempo da Igreja" encontra na pregação da Palavra - bem como no seu anúncio e celebração - o seu clímax. Ser portadora da Palavra de salvação e ministra de sua celebração, é a principal missão confiada à Igreja: "Portanto, assim como Cristo foi enviado pelo Pai, assim também Ele enviou os Apóstolos (...), não só para pregarem o Evangelho a toda criatura, anunciarem que o Filho de Deus, pela sua morte e ressurreição, nos libertou (...) mas ainda para levarem a efeito o que anunciavam: a obra da salvação através do Sacrifício e dos Sacramentos, sobre os quais gira toda a vida litúrgica". ${ }^{30}$

A Palavra de Deus, "que é proclamada na celebração dos divinos mistérios, não só se refere às circunstâncias atuais, mas também olha para o passado e penetra o futuro, e nos faz ver quão desejáveis são as coisas que esperamos (...)" ${ }^{31} \mathrm{O}$ ato proclamativo da Palavra abraça, dessa forma, todo o arco da historia salutis e nela se torna promessa, cumprimento e expectativa de sua plena realização. Fundindo passado, presente e futuro, a Liturgia da Palavra, mormente na celebração eucarística, se revela como "momentosíntese" de toda a economia salvífica.

Sob o dinamismo de uma "tensão escatológica", a assembleia litúrgica, ao proclamar e celebrar a Palavra de Deus, reconhece e testemunha a presença do próprio Ressuscitado - Ele que é "o mesmo ontem e hoje" e "por toda a eternidade" (Hb 13,8). Dessa forma, a Palavra vivente, no sopro do seu Espírito, impulsiona o seu Corpo eclesial para a última e definitiva etapa do plano divino da salvação. Ao ser arrastada para a consumação dos tempos, graças à força irresistível e vibrante da Palavra, a Igreja se une ao Espírito para clamar de suas profundezas: Maranatha! "Vem Senhor Jesus"! - eco eloquente e incessante que nos chega das primeiras reuniões litúrgicas (cf. Ap 22,17). Com efeito, essa mesma Palavra - que também é "Corpo de Cristo" 32 - não cessa de alimentar a Igreja, "até que Ele venha" (1Cor 11,23).

\footnotetext{
${ }^{30} \mathrm{SC}, \mathrm{n} .6$.

${ }^{31}$ OLM, n. 7.

${ }^{32}$ Cf. VD, n. 56.
} 


\section{A "leitura orante" da Palavra de Deus}

O tema da lectio divina ou "leitura orante" é uma realidade que se verifica em progressivo crescimento na vivência pastoral da Igreja e na experiência dos batizados hoje. Os inícios do resgate dessa práxis eclesial - de cunho bíblico e patrístico - podem ser identificados nos inícios do século passado, ocasião privilegiada do grande esforço de renovação teológico-pastoral do Movimento Litúrgico, essencialmente bíblico, patrístico, ecumênico e pastoral. Tal esforço fez com que o magistério eclesial fosse, progressivamente, se abrindo à consciência da importância da relação que existe entre a bíblia, a liturgia e a vida espiritual. Eis o momento de envolvermos os dois itens anteriormente abordados e fazê-los confluir neste item que agora iniciamos.

A Igreja de nossos dias se percebe numa "nova primavera", particularmente no que tange à redescoberta da lectio divina como uma fonte para a espiritualidade dos cristãos. Ela outra coisa não é senão a expressão daquela "escuta religiosa" ("religiose audiens") que permeou cada etapa do Concílio Vaticano II, conforme anteriormente assinalado. Em virtude disso elegemos como fundamentação deste terceiro item a proposta que nos vem da constituição divina sobre a revelação divina $D e i$ Verbum, posteriormente reafirmada pela Exortação Apostólica pós-sinodal Verbum Domini.

É necessário, por isso, que todos os clérigos e, sobretudo, os sacerdotes de Cristo e outros que, como os diáconos e os catequistas, se consagram legitimamente ao ministério da palavra, mantenham um contato íntimo com as Escrituras, mediante a leitura assídua e o estudo acurado, a fim de que nenhum deles se torne "pregador vão e superficial da palavra de Deus, por não a ouvir de dentro", tendo, como têm, a obrigação de comunicar aos fiéis que lhes estão confiados as grandíssimas riquezas da palavra divina, sobretudo na sagrada Liturgia. Do mesmo modo, o sagrado Concílio exorta com ardor e insistência todos os fiéis, mormente os religiosos, a que aprendam "a sublime ciência de Jesus Cristo" (Fl 3,8) com a leitura frequente das divinas Escrituras, porque "a ignorância das Escrituras é ignorância de Cristo". Debrucem-se, pois, gostosamente sobre o texto sagrado, quer através da sagrada Liturgia, rica de palavras divinas, quer pela leitura espiritual, quer por outros meios que se vão espalhando tão louvavelmente por toda a parte, com a aprovação e estímulo dos pastores da Igreja. Lembrem-se, porém, que a leitura da Sagrada Escritura deve ser 
acompanhada de oração para que seja possível o diálogo entre Deus e o homem; porque "a Ele falamos, quando rezamos, a Ele ouvimos, quando lemos os divinos oráculos". ${ }^{33}$

Essa declaração da Dei Verbum mostra-se como um fruto amadurecido do processo de descoberta e resgate da leitura orante na espiritualidade cristã. Dela podemos extrair três pontos fundamentais no que concerne à relação da Igreja com o texto sagrado das Escrituras. O primeiro deles se encontra na primeira parte do número 25 da Dei Verbum: "É necessário" que todos os que, das mais variadas formas, se consagram ao ministério da Palavra - clérigos e leigos - "mantenham um contato íntimo com as Escrituras, mediante a leitura assídua e o estudo acurado". Antes de tudo, essa veemente exortação do Concílio toca no mais íntimo da vocação batismal cristã: um crescimento em vista do "pleno conhecimento do Filho de Deus" (cf. Ef 4,13), somente possível por meio de uma apaixonada e assídua relação com a Bíblia. O anúncio e a pregação da Palavra decorrem disso, do contrário o ministro se tornaria um "pregador vão e superficial da palavra de Deus, por não a ouvir de dentro".

O segundo ponto decorre de outro pensamento do mesmo número do nosso documento, o qual fazemos questão de matizar, uma vez que parece transpirar uma novidade: a leitura orante e a celebração das Escrituras na liturgia são condição sine qua non para se conhecer Jesus Cristo. Em outros termos, "ignoratio enim Scripturarum ignoratio Christi est" ${ }^{34}$ Em que sentido nos referimos a uma "novidade"? O advérbio empregado pelo texto original da Dei Verbum - "pariter" ("do mesmo modo") - vincula o que foi dito no primeiro ponto com aquilo que se afirma agora. Após ter se referido aos "clérigos e sobretudo os sacerdotes de Cristo e outros que, como os diáconos e os catequistas, se consagram legitimamente ao ministério da palavra", agora o foco recai sobre os demais fiéis batizados: "Do mesmo modo, o sagrado Concílio exorta com ardor e insistência todos os fiéis, mormente os religiosos, a que aprendam "a sublime ciência de Jesus Cristo" (F1 3,8) com a leitura frequente das divinas Escrituras, porque "a ignorância das Escrituras é

\footnotetext{
${ }^{33} \mathrm{DV}, \mathrm{n} .25$.

${ }^{34}$ Ao mencionar aqui este adágio de São Jerônimo, o Vaticano II realça que a teologia que está propondo - o resgate da Sagrada Escritura como o centro e alma da espiritualidade da Igreja - é um eco eloquente da teologia e práxis da Tradição. Jerônimo, na verdade, é aqui um qualificado representante da tradição patrística.
} 
ignorância de Cristo". O Concílio exorta, "de forma veemente e peculiar" ("vehementer peculiariterque exhortatur") a todos os que foram incorporados ao Corpo de Cristo pelo batismo a se "debruçarem" "gostosamente sobre o texto sagrado". ${ }^{35}$

É um significativo marco teológico, isso que nos é apresentado pela Constituição Dogmática Dei Verbum: todos os batizados são incisivamente chamados a adquirir a "eminente ciência de Jesus Cristo" através da leitura e do alimento frequente das Escrituras. Nesse sentido se pode falar de "sacramentalidade da Palavra". ${ }^{36}$ Ao tratar do "caráter performativo" da Palavra de Deus na ação sacramental - extensão na lectio divina - e de sua relação com a Eucaristia, Bento XVI lembra que "é possível compreender a sacramentalidade da Palavra através da analogia com a presença real de Cristo sob as espécies do pão e do vinho consagrados [...]. A proclamação da Palavra de Deus na celebração comporta reconhecer que é o próprio Cristo que se faz presente e se dirige a nós para ser acolhido". ${ }^{37}$

O terceiro ponto que ressaltamos do parágrafo 25 da Dei Verbum é o estreitíssimo vínculo que existe entre a lectio divina e a oração: "Lembrem-se, porém, que a leitura da Sagrada Escritura deve ser acompanhada de oração para que seja possível o diálogo entre Deus e o homem; porque 'a Ele falamos quando rezamos, a Ele ouvimos quando lemos os divinos oráculos"”. Com o isso o Concilio deseja enfatizar aquilo que deve caracterizar essencialmente a leitura eclesial da Sagrada Escritura e que sempre constituiu o princípio basilar da espiritualidade bíblico-patrística. O pensamento de Santo Ambrósio é usado pelo documento nesta altura de sua reflexão a fim de ilustrar um

\footnotetext{
${ }^{35}$ Pensamento retomado por Bento XVI na Verbum Domini, n. 86: “Todos os fiéis debrucem-se gostosamente sobre o texto sagrado" ("Libenter igitur ad sacrum textum ipsum accedant").

${ }^{36}$ Sobre o tema da "sacramentalidade da Palavra", conferir: KLOCKNER, M. "Bibbia e liturgia. Quale relazione alla luce dell'Esortazione Apostolica Verbum Domini”. Rivista Liturgica 2 (2012), pp. 260-277; AUGÉ, M., op. cit., pp. 310-320.

${ }^{37} \mathrm{VD}, \mathrm{n} .56$. E ainda continua o parágrafo: "Referindo-se à atitude que se deve adotar tanto em relação à Eucaristia como à Palavra de Deus, São Jerônimo afirma: 'Lemos as Sagradas Escrituras. Eu penso que o Evangelho é o Corpo de Cristo; penso que as santas Escrituras são o seu ensinamento. E quando Ele fala em "comer a minha carne e beber o meu sangue" (Jo 6,53), embora estas palavras se possam entender do Mistério [eucarístico], todavia também a palavra da Escritura, o ensinamento de Deus, é verdadeiramente o corpo de Cristo e o seu sangue. Quando vamos receber o Mistério [eucarístico], se cair uma migalha sentimo-nos perdidos. E, quando estamos a escutar a Palavra de Deus e nos é derramada nos ouvidos a Palavra de Deus que é carne de Cristo e seu sangue, se nos distrairmos com outra coisa, não incorremos em grande perigo?"'.
} 
princípio fundamental e irrenunciável que permeia a espiritualidade patrística no que diz respeito à oração e à leitura orante das Escrituras: "a Ele falamos quando rezamos, a Ele ouvimos quando lemos os divinos oráculos". 38

De grande valor para a espiritualidade dos batizados e a fecundidade de nossas comunidades é a prática da lectio divina, realidade em progressivo crescimento na práxis pastoral de nossos dias. Fortemente estimulada pelo Concílio Vaticano II - que exorta os cristãos ao íntimo contato com as Escrituras, à sua leitura assídua e ao seu diligente estudo ${ }^{39}$ - a leitura orante da Bíblia foi também objeto de preocupação da Exortação Apostólica Verbum Domini. Esse documento volta a lembrar-nos que a "abordagem orante do texto sagrado" é um "elemento fundamental da vida espiritual de todo o fiel, nos diversos ministérios de vida", uma vez que a "Palavra de Deus está na base de toda espiritualidade cristã autêntica". ${ }^{40}$

Na perspectiva da nossa abordagem cremos ser de extrema importância a proposta de uma práxis da leitura orante integrada à celebração eucarística, de modo particular àquela dominical. Nesse sentido, convém recordar o valor ímpar do Ordo Lectionum Missae. Na esteira do Concílio Vaticano II, esse documento ressalta a importância da Palavra na vida dos batizados e na celebração litúrgica da Igreja. Vê-se nele o resgate da espiritualidade da Palavra ao longo de toda a história da salvação. Ao tomar hoje a Escritura em suas mãos, a Igreja se percebe em plena linha de continuidade com a revelação bíblica, sobretudo quando celebra o mistério de sua fé. "Deste modo, a mesma celebração litúrgica, que se sustenta e se apoia principalmente na Palavra de Deus, converte-se num acontecimento novo e enriquece a palavra com uma nova interpretação e eficácia". ${ }^{41}$

A nível pessoal e comunitário - e aqui poderíamos pensar em nossos grupos de oração, nossas comunidades de base, nossos grupos de partilha da Palavra, etc - parece-nos oportuno incentivar uma práxis da lectio divina que tenha como inspiração e paradigma a celebração eucarística do Dia do Senhor.

\footnotetext{
${ }^{38}$ Desse princípio patrístico deriva a seguinte formulação aplicada à leitura orante das Escrituras: "Lectio-meditatio-oratio-operatio-contemplatio".

${ }^{39} \mathrm{DV}, \mathrm{n} .25$.

${ }^{40}$ VD, n. 86. Conferir: BIANCHI, E. Lectio Divina, ontem e hoje. Juiz de Fora: Subiaco, 2005; BIANCHI, E. La lettura spirituale della Bibbia. Casale Monferrato: Piemme, 2000; MORFINO, M. M. Leggere la Bibbia com la vita. Magnano: Qiqajon, 1990; CENCINI, A. A vida ao ritmo da Palavra. Como deixar-se plasmar pela Palavra. São Paulo: Paulinas, 2010.

${ }^{41}$ OLM, n. 3.
} 
O Lecionário Dominical que hoje dispomos, em seus três ciclos, apresentanos uma riqueza insondável do "tesouro da Palavra" que está à espera de ser explorado. Aquela que foi a opção preferencial da Igreja no que concerne à lectio litúrgica, pode se tornar a base fundamental para a leitura orante na vida dos crentes. "Por isso, a Igreja continua fielmente na liturgia o mesmo sistema que usou Cristo na leitura e interpretação das Sagradas Escrituras, visto que ele exorta a aprofundar o conjunto das Escrituras, partindo do "hoje" de seu acontecimento pessoal". ${ }^{42}$

Uma lectio divina que esteja em total sintonia com as leituras bíblicas proclamadas na celebração eucarística ao longo do Ano Litúrgico, certamente pode se constituir numa mistagogia permanente para aqueles que desejam viver e crescer na fé recebida no batismo. Assim como as catequeses mistagógicas, segundo a práxis patrística, eram direcionadas àqueles que haviam sido iniciados na fé cristã - cujo termo era sempre a celebração da Eucaristia -, a "mistagogia" permanente da leitura orante da Escritura poderia se tornar uma práxis pastoral que outra coisa não visa senão àquele que foi o desejo Concílio Vaticano para todo o Povo de Deus: "Na celebração litúrgica é máxima a importância da Sagrada Escritura". ${ }^{43}$ Alimentados e cada vez mais transformados pela Palavra celebrada, estaremos em melhores condições de testemunhar essa mesma Palavra com as nossas próprias vidas. A lex vivendi, nesse sentido, conforme no-lo testifica a permanente tradição da Igreja, depende visceralmente da lex celebrandi da Palavra de Deus.

\section{Conclusão}

Aportamos nesta conclusão lançando um olhar para um mar aberto que nos provoca a continuar: "Deixa uma estrada de prata, aberta para eu passar. Caminho por sobre as ondas; não para de caminhar. O longe é sempre mais longe. Ai de mim se me cansar!". Com esse trecho do poema do escritor e poeta português Armando Corte Rodrigues - "Canção do mar aberto" -, simbolizamos o sentido do trajeto por nós percorrido até aqui, norteado pela "bússola" da proposta: "Bíblia e Liturgia: da Dei Verbum à Verbum Domini".

Ao longo da nossa exposição procuramos ser fiéis à dupla equação que se apresenta no título deste artigo: a primeira se refere à relação ontológica e

${ }^{42}$ Ibidem.

${ }^{43}$ SC, n. 24. Conferir: LÓPEZ MARTÍN, J. No Espírito e na verdade. Introdução teológica à liturgia. Volume I. Petrópolis: Vozes, 1996, pp. 225-252. 
vital que existe entre a Sagrada Escritura e o mistério da liturgia; a segunda diz respeito a dois documentos magisteriais, distantes pelo chrónos e entranhadamente próximos pelo kairós. Referimo-nos aos quase cinquenta anos que separam a Dei Verbum da Verbum Domini, mas, sobretudo, à dependência e evolução que existe entre ambos. Numa perspectiva evolutiva e dinâmica, potencializada pela ação do Espírito Santo no Corpo de Cristo e em cada um de seus membros, reafirmamos que a Palavra de Deus continua a crescer e progredir. De fato, a "Igreja, no decurso dos séculos, tende continuamente para a plenitude da verdade divina, até que nela se realizem as palavras de Deus" (DV 8).

Tanto na Dei Verbum como na Verbum Domini constatamos uma preocupação fundamental de se enfatizar com veemência um dado intrínseco e constitutivo da própria Escritura e da Tradição dos Padres da Igreja: "Considerando a Igreja como "casa da Palavra", deve-se antes de tudo dar atenção à Liturgia sagrada. Esta constitui, efetivamente, o âmbito privilegiado onde Deus nos fala no momento presente da nossa vida: fala hoje ao seu povo, que escuta e responde. Cada ação litúrgica está, por sua natureza, impregnada da Sagrada Escritura" (VD 52).

É nessa moldura - a celebração litúrgica como o locus privilegiado da proclamação das Escrituras e, mais ainda, lugar em que elas "se tornam" Palavra para a assembleia dos crentes - que vislumbramos a realidade da lectio divina ou "leitura orante" da Bíblia, que, conforme acenamos, se encontra num dinamismo crescente na consciência eclesial de nossos dias. A respeito dessa constatação lançamos um vislumbre profético e continuamos a caminhar, expressando-nos mais uma vez com as palavras do poeta: "Caminho por sobre as ondas; não paro de caminhar. O longe é sempre mais longe. Ai de mim se me cansar!".

\section{Referências bibliográficas}

ALDAZÁBAL, J. (Org.). Mesa da Palavra. Volume I. Elenco das leituras da Missa. São Paulo, Paulinas, 2007.

AUGÉ, M. "La Parola di Dio celebrata. Dalla Sacrosanctum Concilium alla Dei Verbum". Rivista Liturgica 2 (2012), pp. 307-320.

BECKÄUSER, A. (Org.). Sacrosancum Concilium. Texto e comentário. São Paulo: Paulinas, 2012. 
BENTO XVI. Exortação Apostólica pós-sinodal Verbum Domini. São Paulo: Paulinas, 2010.

BIANCHI, E. "La centralità della Parola di Dio". In: ALBERIGO, G.; JOSSUA, J. (Orgs.). Il Vaticano II e la Chiesa. Brescia: Paideia, 1985.

BIANCHI, E. L'Amore vince la morte. Commento esegetico spirituale alle lettere di Giovanni. Torino: San Paolo, 2008.

BIANCHI, E. La lettura spirituale della Bibbia. Casale Monferrato: Piemme, 2000.

BIANCHI, E. Lectio Divina, ontem e hoje. Juiz de Fora: Subiaco, 2005.

BOTTE, B. O Movimento Litúrgico. São Paulo: Paulinas, 1978.

CALATI, B. "Rivelazione e/o Tradizione. Il capitolo II della Dei Verbum". In: CALATI, B. et alii. Un documento dimenticato. La "Dei Verbum". Reggio Emilia: San Lorenzo, pp. 11-24.

CAPIZZI, N. Dei Verbum. Storia, commento recezione. Roma: Studium, 2015.

CENCINI, A. A vida ao ritmo da Palavra. Como deixar-se plasmar pela Palavra. São Paulo: Paulinas, 2010.

CONCÍLIO VATICANO II. Constituição Dogmática Dei Verbum, sobre a revelação divina. São Paulo: Paulinas, 1966.

De ZAN, R. “Verbum Domini” y Liturgia. Phase 302 (2011), pp. 147-160.

KLOCKNER, M. 'Bibbia e liturgia. Quale relazione alla luce dell'Esortazione Apostolica Verbum Domini”. Rivista Liturgica 2 (2012), pp. 260-277.

LATOURELlE, R. (Org.). Vaticano Il. Bilancio e prospettive. Venticinque anni dopo. Assisi: Cittadella, 1987.

LATOURELlE, R. (Org.). Come Dio si rivela ao mondo. Assisi: Cittadella, 2000.

LÓPEZ MARTÍN, J. No Espírito e na verdade. Introdução teológica à liturgia. Volume I. Petrópolis: Vozes, 1996.

MAGGIONI, B. "Impara a conoscere il volto di Dio nelle parole di Dio": Commento alla Dei Verbum. Padova: Messaggero Padova, 2009.

MAGRASSI, M. Viver a Palavra. São Paulo: Paulinas, 1984. 
MARSILI, S. “Aliturgia. Momento histórico da salvação”. In: NEUNHEUSER, B. et alii. A Liturgia. Momento histórico da salvação. Volume I. São Paulo: Paulinas, 1987, pp. 39-190.

MARTINEZ DE OLIVEIRA, F. “A constituição dogmática Dei Verbum e o Concílio Vaticano II”. Cadernos de Teologia Pública 102 (2015), pp. 1-23.

MORFINO, M. M. Leggere la Bibbia com la vita. Magnano: Qiqajon, 1990.

PACOMIO, L. Dei Verbum. Genesi della costituzione sulla divina rivelazione. Torino: Marietti, 1971.

PONTIFÍCIA COMISSÃO BÍBLICA. O povo judeu e suas Sagradas Escrituras. São Paulo: Paulinas, 2002.

TESTAFERRI, F. La Parola viva. Assisi: Cittadella, 2009.

\section{Luiz, Fernando Ribeiro Santana}

Doutor em Teologia pela Pontifícia Universidade Católica do Rio de Janeiro Professor do Instituto Superior de Teologia da Arquidiocese do Rio de Janeiro Professor do Departamento de Teologia da Pontifícia Universidade Católica do Rio de Janeiro Rio de Janeiro / RJ - Brasil E-mail: 1.fernando2250@gmail.com

Recebido em: 15/12/2016 Aprovado em: 21/03/2017 